\title{
Anna SZEWCZYKOWSKA
}

Uniwersytet Humanistyczno-Przyrodniczy im. J. Długosza w Częstochowie

\section{GRZECZNOŚĆ KLUCZEM DO ZYSKANIA PRZYCHYLNOŚCI SLUCHACZY W OPARCIU O WYKLADY TADEUSZA ZIELIŃSKIEGO (1859-1944)}

\section{AFFABILITY AS A STRATEGY FOR WINNING OVER AUDIENCES BASED ON TADEUSZ ZIELIŃSKI'S LECUTRES (1859-1944)}

Tadeusz Zieliński was an outstanding scholar specialising in Greek and Roman literature as well as an accomplished orator, though nowadays he is not always appreciated. The best example of his vast knowledge and oratorical talent is undoubtedly the cycle of eight lectures on the broadly conceived Antiquity. In those lectures, Zieliński discussed the ancient world in terms of scientific research, its influence on modern culture and its role in educating the young generation.

In order to ensure the effectiveness of his message, he first had to win favour with the audience. His prestige in the scientific community greatly facilitated it, while the numerous rhetorical and linguistic devices he used guaranteed that his persuasive message brought the expected results. Coherent and logical composition, clear and vivid language, topoi, expressions and phrases aimed at reducing the distance between the sender and the receiver, adjusting the style to the audience, numerous examples, references to authoritative figures, among other things, played a vital role here. Such devices were as important as the contents of the text itself as they ensured the effectiveness of the communication.

Keywords: politeness, rhetoric, lecture, orator, antiquity

Cykl ośmiu wykładów Świat antyczny a my ${ }^{1}$ wygłoszony w 1901 roku w Petersburgu stanowi istotny element bogatej twórczości Tadeusza Zielińskiego. Świadczą nie tylko o ogromnej wiedzy, kunszcie literackim, ale przede wszyst-

${ }^{1}$ Wszystkie cytowane fragmenty wykładów pochodzą z polskiego wydania z 1970 roku. W nawiasie podana zostaje lokalizacja. Tytuł książki Po co Homer? pochodzi od wydawcy. Jest to parafraza pytania z utworu Hölderlina Brot und Wein: „(...) wozu Dichter in dürftigen Zeit?” Pierwotnie wykłady powstały w jęz. rosyjskim (prwdrk ros.: Driewnij mir i my - „Żurnał Ministerstwa Narodnawo Proswieszczinija”, cz. 348 i cz. 349), pierwsze wydanie polskie: Zamość 1922, Z. Pomarański i Ska. 
kim odsłaniają przed nami niezwykle utalentowanego mówcę, dla którego wartość słowa mówionego odgrywała niebagatelną rolę. Tym trudniej było mu się pogodzić z faktem, że słowo mówione ${ }^{2}$ jest wypierane przez słowo pisane, które nigdy w pełni nie odda charakteru mowy. Zieliński postulował więc, aby „wszelkimi sposobami sprzyjać rozwojowi słowa mówionego" (Zieliński 1999: 86), co sam zresztą czynił. Chciał też, aby:

przywrócić naszemu słowu tę naturalność, która była mu niegdyś właściwa, żeby nauczyło nas ono władać mową w taki sposób, by wyrażała w pełni to, co przeżywamy w swojej duszy (ibid.).

Potęgi mowy Zieliński upatrywał już w starożytności, kiedy to właśnie słowo mówione dominowało bezsprzecznie. Był to czas, kiedy:

przyznawano mu wielką chwałę: utożsamiano je z rozumem (...). I coraz silniejsze stawało się przekonanie: logos rządzi światem - to głęboko uzasadnione, mistyczne przekonanie zostało usankcjonowane w początkowych słowach czwartej Ewangelii. To była prawdziwa apoteoza życiodajnego i władającego życiem słowa. Wielka siła, która narodziła się przy końcu świata starożytnego, uznała nie tylko przewodnią rolę słowa, ale i jego boskość (Zieliński 1999: 82).

Przypisanie mu boskiego pierwiastka sprawiło, że zyskało ono moc szczególną, stanowiącą o sile jego przekazu.

Najlepszym dowodem na to, jak bardzo Zieliński cenił sobie język mówiony, są jego liczne odczyty i wykłady, których z przyjemnością się podejmował i dzięki którym świat poznał wielkiego naukowca, a on sam zyskał sławę, czego efektem była nominacja do Nagrody Nobla ${ }^{3}$. Kazimierz Kumaniecki natomiast na łamach Meandra z 1959 roku nazwał go:

najwybitniejszym filologiem klasycznym, jakiego Polska w swej historii wydała, a również jednym z najwybitniejszych i najbardziej oryginalnych badaczy świata antycznego, jacy w ogóle istnieli (Kumaniecki 1959: 8-9).

Zieliński, jako filolog klasyczny, uważał, że jego powinnością, wręcz misją jest dzielenie się swoją wiedzą, propagowanie i zachęcanie do jej zgłębiania. Temu też miał służyć cykl wygłoszonych w Petersburgu ośmiu wykładów poświęconych czasom starożytnym. W swoim wystąpieniu Zieliński rozpatrywał świat antyczny w trzech aspektach, ściśle ze sobą powiązanych - jako cel badań naukowych, jako element współczesnej kultury i jako przedmiot szkolny.

Zieliński podjął się nie lada zadania, zwłaszcza jeżeli będziemy mieć na uwadze, że był to niesprzyjający czas dla badań nad antykiem. W dobie odkryć, jakie niosła ze sobą nowa epoka, kultura antyczna dla wielu mogła wydać się anachronizmem. Jej przeciwnicy uważali, że:

2 Słowo mówione jest tematem licznych rozpraw. Na uwagę zasługują dwa opracowania: Kram 1976 oraz Kotlarczyk 1965.

${ }^{3}$ Więcej informacji z biografii T. Zielińskiego zob. Zieliński 1999: 5-23 lub Britannica 2005. 
jest nauką przetrząśniętą wzdłuż i wszerz; nauką, która żadnych już ciekawych zagadnień nie stawia przed pracą twórczą; (...) jako pierwiastek kultury współczesnej, pozbawiona jest wszelkiego znaczenia, gdyż z dawien dawna prześcignęły ją postępy myśli nowoczesnej; (...) jest to jakiś dziwny przeżytek, nie wiadomo po co i niewiadomo jak, w szkole współczesnej zachowany; przeżytek, który należałoby jak najrychlej i raz na zawsze usunąć (Zieliński 1970: 6).

Wobec takiego stanowiska, tak twardych i kategorycznych zarzutów, argumenty merytoryczne mogły okazać się niewystarczające. W pierwszej kolejności należało zyskać przychylność słuchaczy. Szeroko pojęta grzeczność jest tutaj warunkiem niezbędnym. O tym, jak ważną rolę odgrywa ona w naszym życiu przekonuje M. Barbasiewicz w Dobrych manierach w przedwojennej Polsce:

Przestrzeganie pewnych ustalonych form towarzyskich rozstrzyga nieraz o powodzeniu i wspomaga w przebijaniu się przez życie (Barbasiewicz 2012: 15).

Znajomość zasad dobrego wychowania zawsze była wysoko ceniona. Na przestrzeni wieków zmieniały się jedynie formy i konwenanse wynikające z przemian na podłożu historycznym, kulturowym czy obyczajowym. O grzeczności pisała m.in. Konstancja Hojnowska, autorka jednego z przedwojennych podręczników savoir-vivre’u pt. Wspólżycie z ludźmi: kodeks towarzyski. Jej zdaniem:

Prawdziwie dobre wychowanie to nie szereg wyuczonych gestów codziennych, to nie bezduszna tresura, ale przede wszystkim wskroś życzliwe ustosunkowanie się do ludzi, wyrażające się w postrzeganiu tego, ażeby nikt w naszej obecności a zwłaszcza z naszego powodu nie doznał przykrości (Hojnowska 1939: 5).

„Życzliwe ustosunkowanie się do ludzi” to nic innego jak pozyskanie ich przychylności, wartości nieocenionej w wystąpieniach publicznych. Zdaniem Mirosława Korolko, captatio benevolentiae:

zyskuje ten mówca, którego konkretne wystąpienia oratorskie wspierają ogólne kwalifikacje intelektualne i moralne. Decydujące znaczenie ma tu autorytet mówcy, jego przekonania, pozycja społeczna itp. (...) Prócz tych ogólnych przesłanek składających się na sylwetkę mówcy (...) zaleca się stosowanie pewnych konwencjonalnych schematów, traktowanych jak loci communis sztuki oratorskiej. Do takich zaliczano toposy skromności, zwięzłości, dedykacji, polegające na użyciu stosownych słów, utartych zwrotów (...) (Korolko 1990: 79-80).

Tak pokrótce wygląda charakterystyka grzeczności językowej z punktu widzenia retoryki. Wszystko zależy od mówcy, jego umiejętności i predyspozycji oratorskich.

Wyżej wspomniane podstawowe wyznaczniki grzeczności językowej możemy odnaleźć w wykładach Tadeusza Zielińskiego. Ich zbadanie jest jednak nieco utrudnione, ponieważ dysponujemy jedynie słowem pisanym. Tymczasem o wartości wykładów, jako formy oralnej, decyduje w znacznej mierze jej część niewerbalna. Niemałą rolę odgrywają tutaj język ciała, a więc postawa prelegenta, 
gestykulacja czy mimika. Ważny jest również ton głosu mówcy, przy pomocy którego na przykład akcentuje ważniejsze partie mowy. My jesteśmy takich informacji pozbawieni. Nie mamy też możliwości przyjrzeć się słuchaczom, których reakcja na głoszone treści mogłaby być jedną z wartości kluczowych w ocenie wykładu. Do zbadania pozostaje nam więc warstwa językowa, wbrew pozorom bardzo bogata i zróżnicowana, w której nie brakuje przykładów świadczących o umiejętnościach oratorskich prelegenta, jak również o jego dobrych manierach, przy pomocy których zjednuje sobie słuchaczy. Gama środków pozwalających na zdobycie przychylności słuchaczy jest bardzo szeroka, jako że ,grzeczność językowa jest zjawiskiem wieloaspektowym" (Marcjanik 2007: 12), a o doborze środków niezbędnych do pozyskania życzliwości audytorium decyduje już sam autor wystąpienia.

Zieliński na wiele sposobów realizuje zasadę captatio benevolentiae. Już fakt, że jest on autorytetem w swoje dziedzinie, wysoko cenionym w środowisku naukowym nie pozostaje bez znaczenia. Ma już na swoim koncie wiele osiągnięć. Podczas swoich wykładów Zieliński jednak o nich nie wspomina. Przekazując nam informacje na swój temat, wybiera tylko te, które pozwalają na zbudowanie pozytywnego wizerunku w oczach słuchaczy i są one niezbędne z punktu widzenia aktualnie omawianego tematu.

Jak przystało na dobrego mówcę, który zna zasady dobrego wychowania, Zieliński już w pierwszym wykładzie nam się przedstawia, zaraz na początku. Dowiadujemy się kim jest, jaki cel mu przyświeca i w jaki sposób zamierza go zrealizować:

Zadanie moje polega na tym, ażeby, o ile na to czas i siły mi pozwolą, wyłożyć wam, panowie, znaczenie tej dziedziny wiedzy, której jestem przedstawicielem na tutejszej wszechnicy, a którą dla krótkości, nazywać będę światem antycznym. Zadanie to rozwiązać można w sposób trojaki, odpowiednio do potrójnego znaczenia samego świata starożytnego. Świat ów, nasamprzód, stanowi przedmiot nauki, którą przyjęto - acz niezupełnie słusznie - nazywać filologią klasyczną; po wtóre, stanowi on pierwiastek współczesnej kultury umysłowej i moralnej społeczeństwa europejskiego; po trzecie - i to jego znaczenie najbliżej was dotyka - wchodzi on w skład przedmiotów uprzywilejowanego typu szkoły średniej, tak zwanego gimnazjum klasycznego (Zieliński 1970: 5).

W kolejnych wykładach informuje audytorium, że kiedyś pracował jako nauczyciel, podobnie jak zgromadzeni w sali słuchacze. Doskonale ich więc rozumie:

Sam posługiwałem się nimi, gdym był nauczycielem w klasie pierwszej; pamiętam, jak dziwaczne skojarzenia niebywałych słów i pocieszne rymy wywoływały zdrowy śmiech dziecięcy śród mych uczniów, zwłaszcza gdym, pod koniec lekcji, kazał im chórem powtarzać reguły rytmiczne, a ponieważ poczytywałem zdrowy humor za bardzo „pożyteczny” pojazd (jak mówią lekarze) podczas wykładów w klasach młodszych, więc owe finały lekcy zamieniały się w pewnego rodzaju wesołą grę i gdyby po lekcjach takich lekarz szkolny raczył cyrklem zmierzyć stępienie nerwów u moich malców, to byłby on, sądzę, zupełnie zadowolony (Zieliński 1970: 30-31). 
Zieliński wspomina, w jaki sposób uczył dzieci występujących w łacinie wyjątków. Z powyższej wypowiedzi możemy wywnioskować, że znał się na swojej pracy i czerpał z niej satysfakcję. Można zauważyć, że potrafił umiejętnie łączyć naukę z zabawą, co w przypadku uczenia małych dzieci jest wręcz niezbędne. Różnymi sposobami szukał drogi, żeby dotrzeć do swoich uczniów. Taka postawa mogła się podobać profesorom uczestniczącym w wykładzie. Zieliński udowodnił tutaj dwie rzeczy. Po pierwsze, że był dobry nauczycielem, po drugie, jego wiedza poparta była praktyką i doświadczeniem, dzięki czemu w oczach swojego audytorium stał się wiarygodniejszy. W ten sposób Zieliński buduje płaszczyznę porozumienia, opartą w znacznym stopniu na podobieństwie ${ }^{4}$.

Z kolejnych wykładów dowiadujemy się, że należał również do komisji, do zadań której należało m.in. przygotowanie reformy szkolnictwa. $Z$ pełnienia tej funkcji był szczególnie dumny. Sam wielokrotnie podkreślał, że zmiany w szkołach były bardzo potrzebne. Miał tylko wątpliwości, co do ich kierunku. Rozważał, czy na pewno dobrym posunięciem będzie rezygnacja z czytania przez uczniów dzieł w oryginale. W niektórych przypadkach było to uzasadnione stanowisko. Trzeba mieć jednak na uwadze, że przekład nie zawsze oddaje istotę rzeczy, z czego Zieliński doskonale zdawał sobie sprawę, jako że sam też był tłumaczem:

Sam występowałem w roli tłumacza i wydałem bardzo pokaźny objętością tom, który mam nadzieję, zajmie nieostatnie miejsce w nowożytnej literaturze przekładowej: ale właśnie dlatego wiem, co przekład może oddać, a czego nie może (Zieliński 1970: 50).

Zieliński po raz kolejny udowodnił, że zna się na rzeczy i w tej kwestii można mu zaufać. Pozyskanie zaufania to sprawa niezwykle istotna z punktu widzenia oratora. Dzięki temu znacznie łatwiej dotrzeć do audytorium.

$\mathrm{Na}$ siłę oddziaływania wpłynął też z pewnością sposób, w jaki Zieliński zwracał się do swoich słuchaczy. Oczywiście należało zachować wszelkie przyjęte formy grzecznościowe, jako że „używanie stosownych retorycznie sposobów nazywania rozmówcy ma duży wpływ na skuteczne oddziaływanie perswazyjne" (Marcjanik 2013: 81). Zieliński do uczestników wykładu zwracał się za pomocą lakonicznej formy „Panowie” lub „Państwo”. Są to formy neutralne, w których nie ma miejsca ani na emocje ani na wartościowanie. Często dodawał tutaj czasownik w drugiej osobie liczby mnogiej, np.

Jak widzicie ze słów powyższych, nie należę do bezwzględnych przeciwników przekładów (Zieliński 1970: 50).

Spróbujcie spojrzeć w teraźniejszość tak, jak gdybyście w dniu dzisiejszym się urodzili, bez żadnej wiedzy o dniu choćby wczorajszym (...) (Zieliński 1970: 94).

Nie chcę, abyście cokolwiek brali ode mnie bez należytej, że tak powiem, rewizji celnej (...) (Zieliński 1970: 17).

${ }^{4}$ Więcej o roli podobieństwa w budowaniu pozytywnych relacji międzyludzkich zob. Cialdini 1994: 161-163. 
Taka forma „z psychologicznego punktu widzenia wprowadza poczucie zmniejszenia dystansu i oficjalności stosunków między nadawcą i odbiorcami (Rusinek, Załazińska 2005: 58). Zieliński posługuje się nią równie często, jak pierwszą osobą liczby mnogiej, identyfikując się tym samym ze swoim audytorium, np.

My wszyscy, pracujący na polu starożytności w poczuciu wagi swej pracy dla współcześników i potomnych - my wszyscy jednogłośnie protestujemy przeciw stanowisku narzucanemu nam... (Zieliński 1970: 68).

My zaś szukamy w świecie starożytnym tego, co jednakowo przydać się może zarówno klasykom, jak romantykom i naturalistom - szukamy, zgodnie z tym, co wielokroć wypowiadałem, nie normy, ale ziarna siewnego (Zieliński 1970: 97).

Jeśli my, zagłębiamy się swymi myślami w daleką kultury naszej przeszłość, to nie w tym celu, aby oderwać się od współczesności, ale w tym, aby ją lepiej i łatwiej pojąć, aby od rzeczy warunkowych i przejściowych wznieść się ku bezwarunkowym i wiecznym lub, przynajmniej, długotrwałym; (Zieliński 1970: 95).

Natomiast pojawiające się ,zwroty o charakterze dialogicznym mają na celu skłonienie audytorium do wspólnego z nadawcą myślenia na określony temat" (Marcjanik 2009: 88).

Wskażę wam niektóre drogi do rozwiązania tego zagadnienia, nastręczające się umysłowi człowieka nie przygotowanego (Zieliński 1970: 18).

(...) musicie przyznać, że antytez ostrzej zarysowanych niepodobna było sobie wyobrazić (Zieliński 1970: 6).

Proszę was, panowie, abyście na serio zważyli te wywody, które tu rozwijam - nie wątpię, że wielu z was słyszy je po raz pierwszy - i nie brali na wiarę pociech przeciwników moich, którzy to, co ja nazywam zubożeniem, podają za naturalność i prawią wam o urokach prostoty (Zieliński 1970: 46-47).

Zieliński w pewien sposób narzuca odbiorcom określony punkt widzenia, zwracając jednocześnie uwagę na istotne elementy. Robi to jednak w sposób grzeczny. W pewnym sensie występuje tu w roli przewodnika po antyku, któremu należy zaufać, który wskaże właściwą drogę, tym bardziej, że „droga prawdy jest tylko jedna, dróg błędnych bywa niezliczone mnóstwo" (Zieliński 1970: 13), dlatego on, jako znawca swojej dziedziny stara się naprowadzić słuchaczy na właściwe tory myślenia. Podkreśla jednocześnie: „Przyjemnie bywa wskazać błądzącemu drogę prawdziwą, ale nie należy do przyjemności demaskowanie oszustów" (Zieliński 1970: 114). Zieliński nie czerpie satysfakcji z możliwości udowodnienia komuś jego braków czy błędnego toku rozumowania. Jest to wręcz nie na miejscu. Nawet, jeżeli to robi, jest to krytyka wyważona, uzasadniona, nawet można powiedzieć konstruktywna:

mniemanie ogółu, o ile wyraża się w świadomym lekceważeniu starożytności, nie może co do stopnia powagi iść w porównanie z tym szacunkiem nieświadomym, jaki żywi dla niej tenże ogół; z szacunkiem, który sprawia, że wpływ starożytności na pokolenia potomne trwa ustawicznie, w ciągu tylu wieków, po upadku świata antycznego (Zieliński 1970: 113). 
Zieliński, choć wielokrotnie musi się bronić przed krytyką, nigdy nie przekracza granic dobrego wychowania. Zbija argumenty przeciwników, ale ich nie obraża:

(...) w wykładach swych staram się tylko charakteryzować swą dziedzinę; niekiedy zmuszony okolicznościami, bronię jej i siebie, ale nigdy na nikogo i na nic nie napadam. Powiem dokładniej: nie tylko nie miałem zamiaru obrazić kogokolwiek - nie obraziłem nikogo (...) (Zieliński 1970: 34).

Jedynym orężem mówcy powinny być mocne argumenty „,ażeby istotnie posiadały one moc przekonywającą" (Zieliński 1970: 81). Każdy szanujący się mówca powinien mieć tego świadomość. Są zasady, których trzeba bezwzględnie przestrzegać. Zieliński mówi wręcz o kodeksie honorowym myśliciela, zgodnie z którym należy zaakceptować udowodnioną tezę, bez względu na to, czy się z nią zgadzamy, czy też nie (Zieliński 1970: 80).

Przestrzeganie reguł panujących w świecie retoryki nie tylko wpływa na jakość wystąpienia, ale też na jego kształt. Kompozycja odgrywa więc tutaj rolę kluczową ${ }^{5}$ Krzysztof Szymanek w Sztuce argumentacji podaje następującą definicję kompozycji: to „dział tradycyjnej retoryki traktujący o zagadnieniach konstrukcji wypowiedzi z punktu widzenia jej komunikatywności, perswazyjnej skuteczności oraz walorów estetycznych" (Szymanek 2012: 171). Dobrze skonstruowana mowa powinna być ukłonem w stronę słuchaczy. Wystąpienie publiczne ma być więc nie tylko poprawne merytorycznie, ale też spójne, napisane w sposób przystępny i rzeczowy, z dużą ilością przykładów obrazujących wybrane tezy.

I takie właśnie były wykłady Zielińskiego - merytorycznie dobrze przygotowane, spójne i przemyślane. Dla słuchaczy jest to też sygnał, że mają przed sobą poważnego i odpowiedzialnego mówcę.

Wykłady zostały przygotowane $\mathrm{z}$ dużą starannością. Podstawę stanowi trójczłonowa budowa, z założeniem, że wstęp i zakończenie, jak to ujęli Michał Rusinek i Anna Załazińska, są to „najważniejsze punkty wypowiedzi - pierwszy przykuwa uwagę słuchaczy, drugi pozostaje w ich pamięci” (Rusinek, Załazińska 2005: 99).

Część pierwszego wykładu stanowi wstęp do całości, w której autor przedstawia temat swojego wywodu, w postaci antytezy. Zostaje tutaj zaprezentowane zestawienie, z jednej strony zarzutów „ogółu” wobec świata starożytnego, z drugiej, ich obrona, płynąca ze strony znawców tematu, do których niewątpliwie zalicza się sam Zieliński (zob. Zieliński 1970: 6). W zakończeniu natomiast, idąc „za przykładem ulubieńca swego Platona” (Zieliński 1970: 126), autor opowiada przypowieść o postępie (zob. Zieliński 1970: 126-127), który jest możliwy tylko dzięki niestrudzonemu wędrowcowi pokonującemu piętrzące się na jego drodze przeszkody w nadziei, że któregoś dnia „wrota raju staną przed nim otworem”

${ }^{5}$ Kompozycja tekstu ujmowana jest na różne sposoby przez poszczególnych badaczy. Por. Lausberg 2002: 493; Ziomek 2000: 119 lub Korolko 1998: 78-97. 
(Zieliński 1970: 127). Innymi słowy, prelegent zaleca, aby jego słuchacze, będący tak jak on filologami klasycznymi, niestrudzenie szerzyli wiedzę o antyku, mimo nieustannych zarzutów kierowanych pod ich adresem.

Zieliński na rozmaite sposoby starał się zachęcić swoich słuchaczy do świata starożytnego. Dla zobrazowania swoich tez używał rozmaitych przykładów, które miały oddziaływać na wyobraźnię jego słuchaczy. Wykorzystywał m.in. miejsca wspólne czyli toposy, za pomocą których nawiązywał nić porozumienia z audytorium. Są to bowiem „takie zdania, kwestie obiegowe, sądy, schematy i obrazy, które są jednakowo rozumiane i przyjmowane przez mówcę i słuchaczy" (Rusinek, Załazińska 2005: 73). I choć nie wprowadzają one nic nowego do sprawy, znacznie ułatwiają prawidłową komunikację. Zdaniem Zielińskiego nie należy rezygnować z nauki łaciny czy greki, tylko z uwagi na pojawiające się od niedawna krytyczne opinie dotyczące niewielkiego pożytku płynącego z ich nauczania:

\begin{abstract}
Zgodzicie się, panowie, z tym, że to jednomyślne świadectwo wieków stanowi fakt o wiele znamienniejszy niźli jednodniowy wyrok współczesnego nam społeczeństwa, choćby nawet jednomyślność tego wyroku mniej była fikcyjna, niż jest. Wspomnijcie obraz, jaki przedstawia Newa, gdy dmie złowrogi dla mieszkańców Petersburga wiatr południowo - zachodni; fale rzeki najzupełniej wyraźnie zawracają na wschód; rzeka, zda się, wraca ku Ładodze, a jednak, mimo to, każdy z was wie, że każda kropla tego jeziora, mocą niewidzialnego, lecz bardzo realnego, naturalnego prądu, przeleje się do Zatoki Fińskiej i że jedynym wynikiem tego prądu przeciwnego, spowodowanego przez wiatr, będzie krótkotrwała powódź w przystani rzecznej (Zieliński 1970: 8).
\end{abstract}

Jako że wykład odbywa się w Petersburgu, a jego uczestnikami są Rosjanie, łatwo im będzie wyobrazić sobie miejsce, do którego odwołuje się mówca. Prelegent w ten sposób wytworzył płaszczyznę porozumienia ze swoimi słuchaczami, ułatwiając im tym samym zrozumienie swojego toku myślenia.

Zdarza się również, że Zieliński, w celu uwiarygodnienia swojej tezy, bądź jej obrony, odwołuje się do autorytetów ${ }^{6}$. I co istotne, nie są to jedynie znani ludzie z czasów antycznych, jak Platon czy Seneka, ale też wszyscy, którzy mieli bądź mają bezpośredni wpływ na epokę, w której żył sam Zieliński. Przykładem może być tutaj Schopenhauer:

Pozwólcie przedstawić mi sąd człowieka, który, jako myśliciel, miał pojęcie o sprawie myślenia, a zarazem jako ojciec psychologii współczesnej, w zagadnieniach psychologicznych, które nas tu zajmują, posiada powagę bezsporną - mianowicie Schopenhauera (Zieliński 1970: 40).

Zieliński pokazuje w ten sposób, że jego wiedza nie ogranicza się jedynie do czasów starożytnych. Uważa też, że jego obowiązkiem, jako filologa klasycznego, jest posiadanie wiedzy z zakresu różnych dziedzin. Tylko tak może stać się „mistrzem swoich uczniów” (Zieliński 1970: 58).

${ }^{6}$ Odwoływanie się do autorytetów stwarza nieograniczone możliwości argumentacji, stąd tak chętnie mówcy z nich korzystają. Zob. na ten temat: Perelman 2002: 127-130. 
I choć Zieliński do swojego tematu podchodzi bardzo poważnie, a swoich słuchaczy traktuje z należytym szacunkiem pozwala sobie również na żarty. Robi to jednak bardzo ostrożnie, żeby nikogo nie urazić:

O Hiszpanach, zresztą, jak musieliście już, panowie, zauważyć, mówię dlatego tylko, że mieszkają oni daleko. Nigdy nie dowiedzą się, że mówiłem o nich, i przeto się nie obrażą, ja zaś tak wielu już w wykładach poprzednich ,poobrażałem”, że nie chciałbym liczby ich powiększać (Zieliński 1970: 78-79).

Wprowadzając żart do swojego wywodu prelegent nie tylko udowodnił, że ma poczucie humoru, ale pokazał również, że jest takim samym człowiekiem jak każdy $\mathrm{z}$ nas.

Takimi właśnie sposobami Zieliński zyskuje sympatię swoich słuchaczy. A jeżeli zwrócimy jeszcze uwagę na język, jakim się posługuje, to zobaczymy, że udało mu się znaleźć złoty środek między formą, a treścią, bowiem „Źle się dzieje, gdy któraś z nich bierze górę. Gdy dominuje forma - jest nieszczerze i fałszywie, gdy treść - bywa niegrzecznie" jak słusznie zauważa Elżbieta Umińska-Tytoń (2004: 713) w swoim artykule Komplementy czyli piękne stówka. Język Zielińskiego jest zróżnicowany, dostosowany do tego, o czym aktualnie opowiada. Bogaty w środki stylistyczne, takie jak epitety, metafory, hiperbole, ale jednocześnie stonowany, rzeczowy i konkretny.

Wybrane przykłady to jedynie niewielka część będąca świadectwem umiejętności retorycznych wykorzystanych do zdobycia przychylności słuchaczy. Pozornie zabiegi te mogą się wydawać mało znaczące, tymczasem odgrywają kluczową rolę w pozyskaniu życzliwości audytorium. Zieliński jako mówca udowodnił, że posiadał ogromny talent oratorski, który w połączeniu z niebywałą erudycją sprawił, że cieszył się on w środowisku naukowym dużym szacunkiem. Wartości, które reprezentuje w swoich dziełach, szczególnie w wykładach, świadczą o nim jako o człowieku prawym, który walory intelektualne antyku cenił na równi z moralnymi. Jego zamiłowanie do prawdy należy jednak rozumieć dwojako. Z jednej strony to rzetelne podejście do nauki, a drugiej, uczciwe traktowanie swoich słuchaczy. W jego rozumieniu Orator est vir bonus. Dla Zielińskiego więc, który traktuje prawdę jako wartość nadrzędną, zdobycie sympatii słuchaczy było naturalną koleją rzeczy.

\section{Bibliografia}

Barbasiewicz, M. (2012). Dobre maniery w przedwojennej Polsce. Savoir-vivre. Zasady. Gafy. Warszawa: Wydawnictwo Naukowe PWN.

Cialdini, R. (1994). Wywieranie wptywu na ludzi. Teoria i praktyka. Przeł. B. Wojciszke. Gdańsk: Gdańskie Wydawnictwo Psychologiczne.

Hojnowska, K. (1939). Wspótżycie z ludźmi. Kodeks towarzyski. Żnin: nakł. i druk A. Krzycki.

Korolko, M. (1998). Sztuka retoryki: przewodnik encyklopedyczny. Warszawa: Wiedza Powszechna. 
Kotlarczyk, M. (1965). Podstawy sztuki żywego słowa. Warszawa: Wydawnictwo Związkowe CRZZ. Kram, J. (1976). Gawędy o żywym stowie. Warszawa: Nasza Księgarnia.

Kumaniecki, K. (1959). „Tadeusz Zieliński”. Meander 8-9.

Lausberg, H. (2002). Retoryka literacka. Podstawy wiedzy o literaturze. Przeł., oprac. i wstępem poprzedził A. Gorzkowski. Bydgoszcz: Wydawnictwo Homini.

Marcjanik, M. (2007). Grzeczność w komunikacji językowej. Warszawa: Wydawnictwo Naukowe PWN.

Marcjanik, M. (2009). Mówimy uprzejmie. Poradnik językowego savoir-vivre’u. Warszawa: Wydawnictwo Naukowe PWN.

Marcjanik, M. (2013). „Retoryczny wymiar językowej grzeczności na przykładzie form adresatywnych w komunikowaniu społecznym". Poradnik Językowy 6. 74-82.

Perelman, Ch. (2002). Imperium retoryki. Retoryka i argumentacja. Przeł. M. Chomisz. Warszawa: Wydawnictwo Naukowe PWN.

Rusinek, M., Załazińska, A. (2005). Retoryka podręczna czyli jak wnikliwie stuchać i przekonująco mówić. Kraków: Wydawnictwo Znak.

Szymanek, K. (2012). Sztuka argumentacji. Stownik Terminologiczny. Warszawa: Wydawnictwo Naukowe PWN.

Umińska-Tytoń, E. (2004). Komplementy czyli piękne stówka. W: A. Tomecka-Mirek. Piękno materialne. Piękno duchowe. Materiały z konferencji 19-21 maja 2003 r. Łódź: Archidiecezjalne Wydawnictwo Łódzkie. 705-723.

Urbanowicz, A. (2005). Zieliński Tadeusz. W: Britannica. Edycja polska. t. 48. Poznań: Wydawnictwo Kurpisz.

Zieliński, T. (1999). Kultura i rewolucja. Publicystyka z lat 1917-1922. Przeł., oprac. i wstępem opatrzyła H. Geremek. Warszawa: Wydawnictwo DiG.

Zieliński, T. (1970). Po co Homer? Świat antyczny a my. Wybór i posłowie A. Biernacki. Kraków: Wydawnictwo Literackie.

Ziomek, J. (2000). Retoryka opisowa. Wrocław: Zakład Narodowy im. Ossolińskich.

mgr Anna Szewczykowska (Uniwersytet Humanistyczno-Przyrodniczy im. Jana Długosza w Częstochowie) - graduated in Polish Philology at Jan Długosz University in Częstochowa. The title of her master thesis was: Witness to the Epoch. Krasiński as an Epistolographer. Currently, her scientific interests are focused on ancient literature. She teaches library science and research information, focusing on publishing and bookselling issues as well as the culture of the region. e-mail: annaszewczykowska1@gmail.com 